\title{
Cutaneous Fibrohistiocytic Neoplasm
}

National Cancer Institute

\section{Source}

National Cancer Institute. Cutaneous Fibrohistiocytic Neoplasm. NCI Thesaurus. Code C7749.

A benign or malignant neoplasm affecting the skin. The tumor is composed of fibrohistiocytic cells, spindle fibrous cells, and histiocytes in a storiform pattern. 